\title{
COMPARATIVE ANALYSIS OF ISLAMIC BANK SOUNDNESS LEVEL
}

\author{
Arfeni Nabila \\ Masters Program of Sharia Finance, ITB Ahmad Dahlan Jakarta \\ Ir. H. Juanda Street No. 77 Tangerang Selatan, Banten, Indonesia. 15419 \\ Email: nabilaarfeni@gmail.com
}

\begin{abstract}
Abstrak: The purpose of this study was to assess the soundness level of Bank Syariah Mandiri, Bank Muamalat Indonesia, and Bank Negara Indonesia Syariah using the RGEC method (Risk Profile, GCG, Earning, Capital) for the 2019 period. The method used is a descriptive research approach, with publication report data. Finance obtained from online media used by Banks with due observance of the RGEC method in the world of Islamic Banking. This study wants to reveal a comparison of the level of health in three Islamic banks. This research was conducted in a limited scope, in terms of GCG factors, data taken from annual reports so that further research data can be processed in the GCG factor in the form of data obtained from the results of questionnaires to bank stakeholders. The range of areas and types of methods used will be more varied with a more diverse sample of banks so as to provide more accurate conclusions. The results showed that Bank Syariah Mandiri, Bank Muamalat Indonesia and Bank Negara Indonesia Syariah as the state-owned banks with the largest assets received a very healthy CAR Composite Rating. This reflects the condition of the three banks which are considered highly capable of dealing with significant negative effects from changes in business conditions and other external factors, however if a weakness occurs, it can be said that in general these weaknesses are not significant even though seen from the ROA Composite Rating Value, Bank Muamalat Indonesia gets unhealthy rating with an ROA value of $0.05 \%$ based on Bank Indonesia Regulation No. 13/1/PBI/2011 concerning Assessment of the Soundness of Commercial Banks with Risk-Profile, Good Corporate Governance (GCG), Earnings, and Capital.
\end{abstract}

Keywords: bank health, capital, RGEC method, rentability

Abstrak: Tujuan dari penelitian ini adalah untuk menilai tingkat kesehatan Bank Syariah Mandiri, Bank Muamalat Indonesia, dan Bank Negara Indonesia Syariah menggunakan metode RGEC (Risk Profile, GCG, Earning, Capital) periode tahun 2019. Metode yang digunakan adalah pendekatan penelitian deskriptif, dengan data laporan publikasi keuangan yang diperoleh dari media online yang digunakan oleh bank dengan memperhatikan metode RGEC dalam dunia Perbankan Syariah. Penelitian ini ingin mengungkap perbandingan tingkat kesehatan di tiga bank syariah. Penelitian ini dilakukan dalam ruang lingkup yang terbatas, dari segi faktor GCG, data diambil dari laporan tahunan sehingga data penelitian selanjutnya dapat diolah dalam faktor GCG berupa data yang diperoleh dari hasil kuesioner kepada pemangku kepentingan bank. Jangkauan wilayah dan jenis metode yang digunakan akan lebih bervariasi dengan sampel bank yang lebih beragam sehingga dapat memberikan kesimpulan yang lebih akurat. Hasil penelitian menunjukkan bahwa Bank Syariah Mandiri, Bank Muamalat Indonesia dan Bank Negara Indonesia Syariah sebagai bank BUMN dengan aset terbesar memperoleh Peringkat Komposit CAR yang sangat sehat. Hal ini mencerminkan kondisi ketiga bank yang dinilai sangat mampu menghadapi dampak negatif yang signifikan dari perubahan kondisi bisnis dan faktor eksternal lainnya, namun jika terjadi kelemahan dapat dikatakan bahwa secara umum kelemahan tersebut tidak signifikan meskipun dilihat dari Nilai Peringkat Komposit ROA, Bank Muamalat Indonesia mendapatkan peringkat tidak sehat dengan nilai ROA 0,05\% berdasarkan Peraturan Bank Indonesia No. 13/1/PBI/2011 tentang Penilaian Tingkat Kesehatan Bank Umum dengan Profil Risiko, Tata Kelola Perusahaan yang Baik (GCG), Laba, dan Modal.

Kata Kunci: kesehatan bank, metode RGEC, permodalan, rentabilitas

\section{Introduction}

An important indicator in seeing a bank's performance is through an assessment of its soundness level so that it can assess the ability of a bank to run its operations, in order to fulfill its obligations and be able to maintain confidence in the bank itself. The main indicator that can be used as a basis for evaluating the health of a bank through financial reports and bank annual reports. The financial report according to PSAK 1 (Revised 2009) aims to provide information about the financial position, financial performance and cash flow of an entity that is useful for users in making economic decisions. Financial reports also show management's accountability for the use of given resources (Sari, 2017). 
The RGEC method is considered capable of measuring the soundness level of a bank and identifying risks that may arise so that appropriate and appropriate corrective actions can be taken. The resulting bank soundness rating can be used as evaluation material so that it is expected to improve and maintain management performance in accordance with banking targets. Reflecting on the importance of the soundness level of a bank that must be maintained and /or improved to maintain trust in the bank, this is what makes researchers interested in conducting research on the Comparative Analysis of the Soundness of Islamic Banks with the RGEC Method (Risk Profile, Good Corporate Governance, Earning, and Capital) at Bank Syariah Mandiri, Bank Muamalat Indonesia, and Bank Negara Indonesia Syariah in the 2019 Period.

The bank soundness assessment is regulated according to Bank Indonesia Regulation and Bank Indonesia Circular Letter concerning Commercial Bank Health Assessment and Commercial Bank Health Assessment Codification, the factors for assessing bank soundness using the RGEC method as follows:

1. Risk Profile is an assessment of inherent risk and the quality of risk management implementation in bank operations carried out on eight risks, namely market risk, credit risk, liquidity risk, operational risk, legal risk, strategic risk, compliance risk and reputation risk. This analysis measures the Risk Profile factor using the Non Performing Loan (NPL) formula and liquidity risk using the Loan to Deposit Ratio (LDR) formula.Good Corporate Governance (GCG), the mandatory assessment of the GCG factor is an assessment of bank management on the implementation of GCG principles. The implementation of the principles of good governance is manifested at least in:

a. Implementation of duties and responsibilities of the Board of Directors and the Board of Commissioners;

b. Completeness and implementation of duties of committees and work units that carry out internal control functions;

c. Application of compliance, internal audit and external audit functions;

d. Application of risk management;

e. Provision of funds to related parties and provision of large funds;

f. The strategic plan; and

g. Transparency of financial and non-financial conditions. Earnings (Rentabilitas), kewajiban penilaian terhadap factor rentabilitas (earnings) meliputi penilaian terhadap kinerja rentabilitas (earnings), sumber-sumber rentabilitas (earnings), dan kesinambungan rentabilitas (earnings' sustainability) bank. Penilaian ini diukur dengan rasio Return on Assets (ROA).

2. Capital (Capital), an assessment of the capital factor (capital) includes an assessment of the level of capital adequacy and management of capital. This assessment is measured by the Capital Adequency Ratio (CAR).

The rating of each factor that is assigned a composite rating is adjusted to the Financial Services Authority Regulation No. 4 / POJK.03 / 2016 concerning Assessment of Bank Soundness Level as follows:

a. Composite Rating 1 (PK-1), reflects a bank's condition that is generally very healthy, so it is considered very capable of facing significant negative effects from changes in business conditions and other external factors.

b. Composite Rating 2 (PK-2), reflects a bank's generally sound condition, so it is considered capable of facing significant negative effects from changes in business conditions and other external factors.

c. Composite Rating 3 (PK-3), reflects the bank's condition that is generally quite healthy, so that it is considered capable of facing significant negative effects from changes in business conditions and other external factors. Composite Rating 4 (PK-4), reflects a bank's condition that is generally unhealthy, so that it is considered less capable of facing significant negative effects from changes in business conditions and other external factors.

d. Composite Rating 5 (PK-5), reflects a bank's condition that is generally unhealthy, so it is considered unable to face significant negative effects from changes in business conditions and other external factors. 
Based on the results of identification and assessment of the Financial Services Authority, it is found that problems or violations significantly affect or will affect the operations and / or business continuity of the Bank, the Financial Services Authority has the authority to lower the Composite Rating of the Bank Soundness Level.

Assessment of bank soundness is carried out by analyzing bank financial ratios through bank financial data presented in bank financial reports using the RGEC method. Each bank is required by Bank Indonesia to assess GCG using the Self Assessment method. Earnings (profitability) is an assessment of the health of a bank in terms of profitability, which is measured by analyzing the ROA ratio. The calculation of the bank soundness rating indicator will give a result determined by a composite rating to determine the bank in the very healthy/healthy/quite healthy/unhealthy/ unhealthy category.

Bank health can be defined as the ability of a bank to carry out normal banking operations. Analysis of bank soundness is an indicator of management success which can be identified by the development of bank soundness from the previous period to the next. Here's a brief chart of the presentation framework:

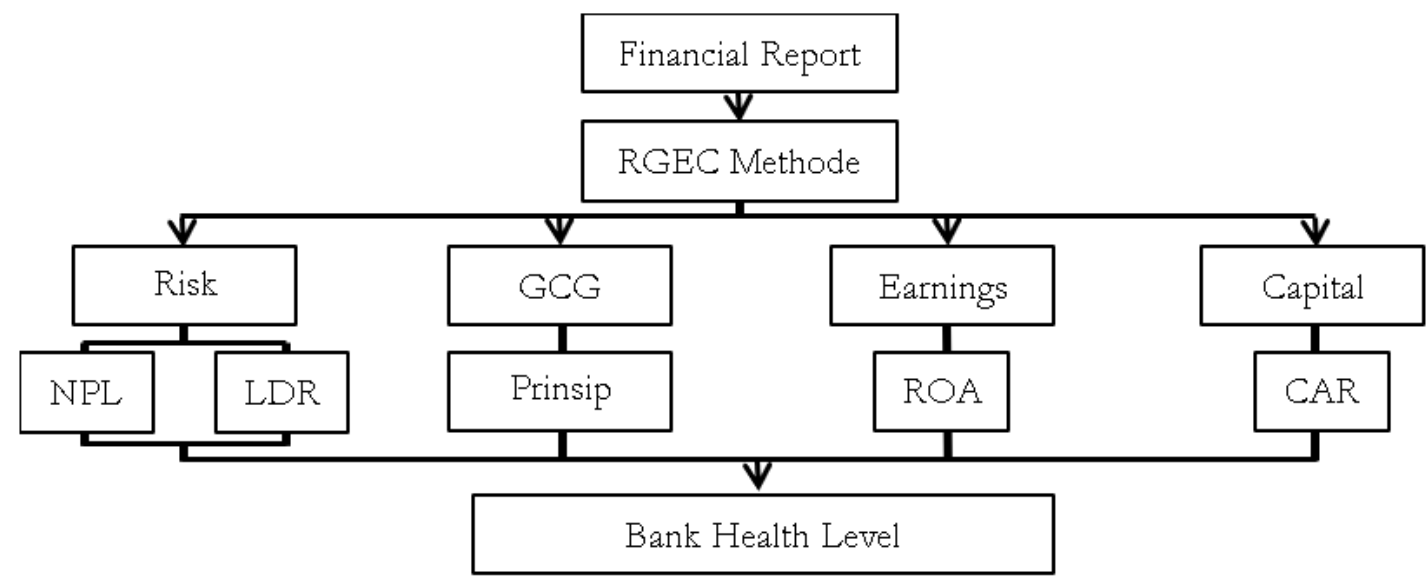

Figure 1. Brief chart of the presentation framework

\section{Materials and Methods}

Data were collected through the provisions stipulated in Bank Indonesia Regulation Number 13/1 /PBI/2011 and Circular Letter Number 13/24/DPNP dated October 25, 2011. Through this descriptive research approach, it attempts to describe and interpret objects according to what they are. Nonexperimental research by not controlling and manipulating variables of phenomena or populations from individual subjects, organizations, industries, or other perspectives.

The bank data analysis technique uses a risk approach, namely the Risk Based Bank Rating (RBBR) by calculating 4 (four) indicators of the RGEC method, namely:

1. Risk Profile, by calculating the Non Performing Loan as an aspect of credit risk and the Loan to Deposit Ratio as an aspect of liquidity risk.

2. Good Corporate Governance (GCG) which is taken from bank reports based on the Self Assessment method.

3. Earnings (Rentability), by calculating Return on Assets (ROA) and Net Interest Margin (NIM).

4. Capital (Capital), by calculating the Capital Adequacy Ratio (CAR).

5. Summarize and determine the bank soundness level Composite Rating (PK) based on a comprehensive analysis.

The rankings for the composite are categorized into 5 (five) composite ratings, namely Composite Rating 1 (PK-1), Composite Rating 2 (PK-2), Composite Rating 3 (PK-3), Composite Rating 4 (PK-4), and Composite Rating 5 (PK-5). The smaller Composite Rating order reflects a more stable bank condition.

\section{Results and Discussion}

\section{A. Analysis of Bank Mandiri Syariah Soundness Level}


The following is an outline of the financial data used to calculate the Bank Soundness Level ratio using the RGEC method:

Table 1. Data of Bank Mandiri Syariah

\begin{tabular}{lc}
\hline Category & 31 December 2019 \\
\hline Non Performing Credit & 2.414 .678 .704 \\
Total Credits & 98.962 .242 .000 \\
Third-party funds & 99.809 .819 .000 \\
Profit before tax & 1.715 .006 .000 \\
Total Assets & 112.291 .867 .000 \\
Bank capital & 9.611 .534 .000 \\
ATMR & 59.514 .517 .000 \\
\hline
\end{tabular}

Source: Financial reports for the period 31 December 2019

a. Risk Profile

The financial ratios used in assessing the soundness level of a bank in terms of risk profile are credit risk using the Non-Performing Loan (NPL) ratio and liquidity risk with the Loan to Deposit Ratio (LDR) ratio, each of which is discussed as follows:

1. Credit Risk with NPL ratio

NPL is the result of a comparison between non-performing loans to total loans. The results of Bank Mandiri Syariah NPL assessment can be seen in Table 2.

Table 2. Results of Bank Mandiri Syariah NPL assessment

\begin{tabular}{cccc}
\hline Period & Non Performing Credit & Total Credit & NPL \% Ratio \\
\hline 2019 & 2.414 .678 .704 & 98.962 .242 .000 & $2.44 \%$ \\
\hline
\end{tabular}

In the 2019 period, Bank Mandiri Syariah showed small non-performing loans with total loans, so that an NPL ratio was obtained of $2.44 \%$. Furthermore, in Table 3 below shows the Composite Rating (PK) Value of Bank Mandiri Syariah NPL, as follows:

Table 3. Composite Rating (PK) value of Bank Syariah Mandiri NPL

\begin{tabular}{cccc}
\hline Period & NPL \% & Rating & Remark \\
\hline 2019 & $2.44 \%$ & 2 & Healthy \\
\hline
\end{tabular}

In the 2019 period, Bank Syariah Mandiri's NPL showed 2.44\% so that it was ranked 2nd with a healthy statement. This is based on PBI No. 13/1 / PBI / 2011 concerning Rating of Commercial Bank Soundness: Banks are required to maintain and / or increase the Soundness of Banks by applying the principles of prudence and risk management in carrying out business activities. Banks that violate provisions according to PBI No. 13/1 / PBI / 2011 will be subject to administrative sanctions.

2. Liquidity Risk with LDR ratio

LDR is the result of a comparison between Total Credit and Third Party Funds (DPK). Bank Mandiri Syariah LDR can be seen in Table 4.

Table 4. Bank Mandiri Syariah LDR

\begin{tabular}{cccc}
\hline Period & Total Credit & DPK & LDR \% Ratio \\
\hline 2019 & 98.962 .242 .000 & 99.809 .819 .000 & $99.15 \%$ \\
\hline
\end{tabular}

In 2019, it appears that the total credit compared to third party funds tends to be less, this affects Table 5 which shows the LDR Composite Rating (PK) Value of Bank Mandiri Syariah, as follows:

Table 5. LDR Composite Rating (PK) value of Bank Mandiri Syariah

\begin{tabular}{cccc}
\hline Period & LDR \% & Rating & Remark \\
\hline 2019 & $99.15 \%$ & 3 & Enough Healthy \\
\hline
\end{tabular}


Bank Mandiri Syariah in 2020 is expected to be able to reduce the LDR ratio to the limit of the LDR ratio which is classified as a healthy predicate to maintain the level of bank liquidity risk. Based on Bank Indonesia Regulation No. 13/1/PBI/2011 concerning Rating of Commercial Bank Soundness: Banks are required to maintain and / or improve the Soundness of Banks by applying the principles of prudence and risk management in conducting business activities. Banks that violate provisions according to PBI No. 13/1/PBI/2011 shall be subject to administrative sanctions, in the form of: written warning, lowering the soundness of the bank, freezing of certain business activities, and / or inclusion of the management and / or shareholders of the Bank in the list of parties that have not passed the predicate and compliance (Fit and Proper Test).

b. Good Corporate Governance (GCG)

Assessment of GCG factors is an assessment of bank management on the implementation of GCG principles as stipulated in Bank Indonesia Regulations. The achievement results are based on the Annual Report from Bank Syariah Mandiri's own self-assessment which can be seen in Table 6.

Table 6. Annual report from Bank Syariah Mandiri's own self-assessment

\begin{tabular}{ccc}
\hline Period & Rating & Remark \\
\hline 2019 & 1 & Very Good \\
\hline
\end{tabular}

In 2019, Bank Mandiri Syariah was ranked 1 which shows a very good value for implementing it. The several awards received by Bank Syariah Mandiri in 2019 include:

a. The Strongest Islamic Retail Bank in Asia by Cambridge Analytica Islamic Finance

b. Good Corporate Governance Award by SWA Magazine \& The Institute for Corporate Governance (IICG)

c. Annual Report Award (ARA) by KNKG, OJK, BI, BEI, Ministry of BUMN, Directorate General of Tax \& IAI

d. Service Excellence (MRI) by Market Research Indonesia \& Infobank Magazine

c. Earnings (Rentability)

The rentability ratio used in this study is Return on Assets (ROA). ROA is the result of a comparison between Profit Before Tax and Total Assets. This ratio is calculated to measure the success of management in generating profits. The smaller this ratio means that bank management is less capable of managing assets to increase revenue and reduce costs. The results of Bank Syariah Mandiri ROA assessment can be seen in Table 7 .

Table 7. Results of Bank Mandiri Syariah ROA assessment

\begin{tabular}{cccc}
\hline Period & Profit before tax & Total asset & ROA \% ratio \\
\hline 2019 & 1.715 .006 .000 & 112.291 .867 .000 & $1.69 \%$ \\
\hline
\end{tabular}

In 2019, it can be seen that the profit before tax is not too large of the total assets owned so that in Table 8 shows the ROA Composite Rating (PK) Value of Bank Mandiri Syariah.

Table 8. ROA Composite Rating (PK) Value of Bank Mandiri Syariah

\begin{tabular}{cccc}
\hline Period & ROA \% & Rating & Remark \\
\hline 2019 & $1.69 \%$ & 2 & Healthy
\end{tabular}

Bank Mandiri Syariah is expected to be able to maintain and increase the ROA ratio so that the bank remains in the healthy category and the profits earned are maintained so that the company does not experience losses and its performance is not hampered.

Based on Bank Indonesia Regulation No. 13/1/PBI/2011 concerning Rating of Commercial Bank Soundness: Banks are required to maintain and / or increase the Soundness of Banks by applying the principles of prudence and risk management in conducting business activities. Banks that violate 
provisions according to PBI No. 13/1/PBI/2011 shall be subject to administrative sanctions, in the form of: written warning, downgrading of bank soundness, suspension of certain business activities, and / or inclusion of Bank management and / or shareholders in the list of parties that have received the predicate of failing to pass the capability assessment and compliance.

d. Capital

The capital ratio used is the Capital Adequacy Ratio (CAR). CAR is a comparison between Bank Capital and Risk Weighted Assets (RWA). The CAR ratio is used to measure the capital adequacy of the bank to support assets that contain or generate risk. The results of the Bank Mandiri CAR assessment can be seen in Table 9 .

Table 9. Results of the Bank Mandiri CAR assessment

\begin{tabular}{cccc}
\hline Period & Bank capital & ATMR & CAR \% Ratio \\
\hline 2019 & 9.611 .534 .000 & 59.514 .517 .000 & $16.14 \%$ \\
\hline
\end{tabular}

The CAR ratio in 2019 was obtained 16.14\% so that Table 10 shows the Composite Rating (PK) Weight of Bank Mandiri Syariah CAR.

Table 10. Composite Rating (PK) weight of Bank Syariah Mandiri CAR

\begin{tabular}{cccc}
\hline Period & CAR & Rating & Remark \\
\hline 2019 & $16.14 \%$ & 1 & Very Healthy \\
\hline
\end{tabular}

Bank Mandiri Syariah is ranked 1 in the very healthy category so it is expected to be able to maintain and maintain the CAR ratio in order to face risks that might occur in the future, due to the smaller CAR ratio, the bank has the potential for difficulties and endangers its sustainability. business both in funding its business activities and the occurrence of risks in the future that may cause losses to the bank.

Based on Bank Indonesia Regulation No. 13/1/PBI/2011 concerning Rating of Commercial Bank Soundness: Banks are required to maintain and / or increase the Soundness of Banks by applying the principles of prudence and risk management in conducting business activities. Banks that violate provisions according to PBI No. 13/1/PBI/2011 shall be subject to administrative sanctions, in the form of: written warning, lowering the soundness of the bank, freezing of certain business activities, and / or inclusion of the management and / or shareholders of the Bank in the list of parties that have received the title of failing to pass the capability assessment and compliance.

Bank Mandiri Syariah health level, can be seen in the Figure 2.

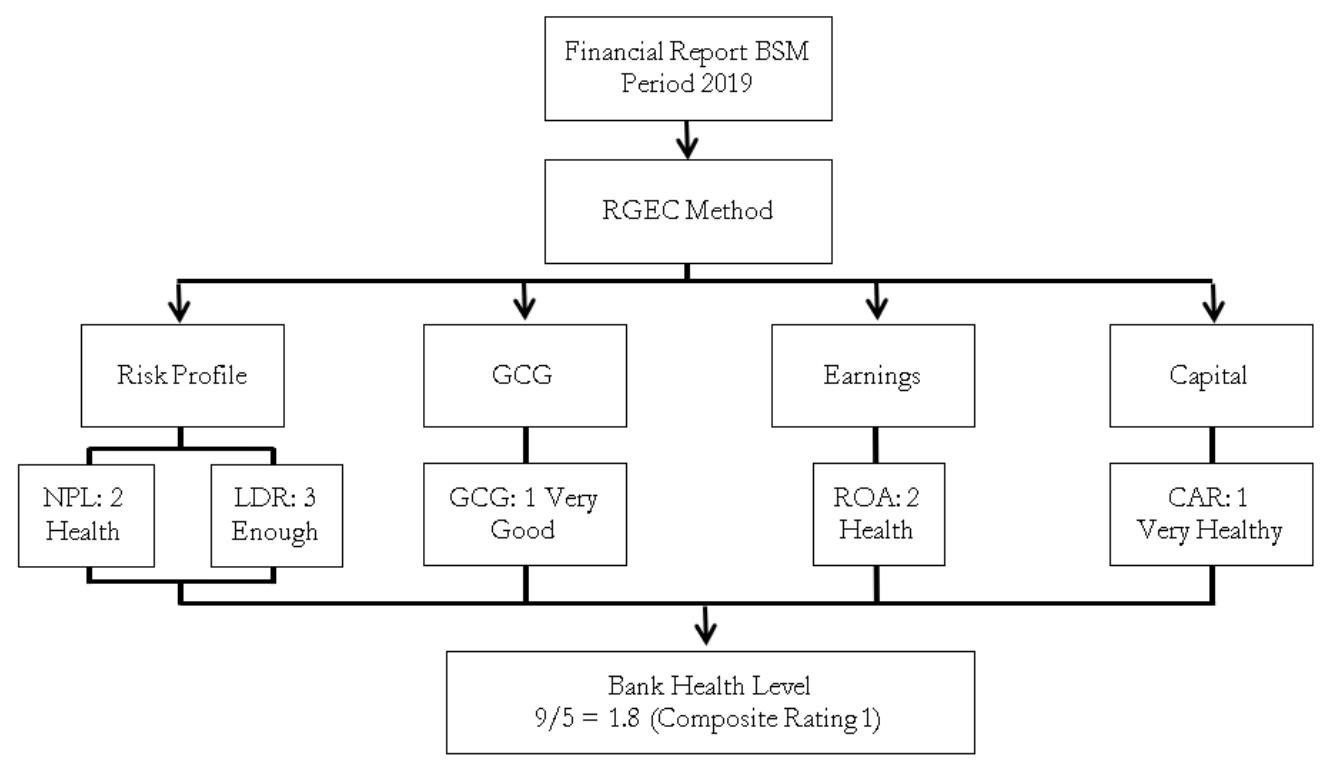

Figure 2. Bank Mandiri Syariah health level 


\section{Analysis of Bank Muamalat Indonesia Health Level}

The following is an outline of the financial data used to calculate the Bank Soundness Level ratio using the RGEC method:

Table 11. Data of Bank Muamalat Indonesia

\begin{tabular}{lc}
\hline Categori & 31 December 2019 \\
\hline Non Performing Credit & 1.827 .724 .640 \\
Total Credits & 35.013 .882 .000 \\
Third-party funds & 40.357 .214 .000 \\
Profit before tax & 26.166 .000 \\
Total Assets & 50.555 .519 .000 \\
Bank capital & 3.871 .341 .000 \\
ATMR & 31.171 .834 .000 \\
\hline
\end{tabular}

Source: Financial reports for the period 31 December 2019

a. Risk Profile

The financial ratios used in assessing the soundness level of a bank in terms of risk profile are credit risk using the Non-Performing Loan (NPL) ratio and liquidity risk with the Loan to Deposit Ratio (LDR) ratio, each of which is discussed as follows:

1. Credit Risk with NPL ratio

NPL is the result of a comparison between non-performing loans and total loans. The results of Bank Muamalat Indonesia's NPL assessment can be seen in Table 12.

Table 12. Results of Bank Muamalat Indonesia's NPL assessment

\begin{tabular}{cccc}
\hline Period & Non Performing Credit & Total Kredit & NPL \% Ratio \\
\hline 2019 & 1.827 .724 .640 & 35.013 .882 .000 & $5.22 \%$ \\
\hline
\end{tabular}

In 2019, Bank Muamalat Indonesia's NPL ratio of $5.22 \%$ shows in Table 13, Bank Muamalat Indonesia's NPL Composite Rating (PK) Value.

Table 13. Bank Muamalat Indonesia's NPL Composite Rating (PK) value

\begin{tabular}{cccc}
\hline Period & NPL \% & Rating & Remark \\
\hline 2019 & $5.22 \%$ & 3 & Enough Healthy \\
\hline
\end{tabular}

In 2019, Bank Muamalat Indonesia was ranked 3rd in the fairly healthy category. There needs to be a systematic improvement and breakthrough to boost the NPL rating so that it will improve further in the future. Without ignoring violations so as not to be subject to administrative sanctions according to PBI No. 13/1/PBI/2011.

2. Liquidity Risk with LDR ratio

LDR is the result of a comparison between Total Credit and Third Party Funds (DPK). Bank Muamalat Indonesia LDR can be seen in Table 14.

Table 14. Bank Muamalat Indonesia LDR

\begin{tabular}{cccc}
\hline Period & Total Credit & DPK & LDR \% Ratio \\
\hline 2019 & 35.013 .882 .000 & 40.357 .214 .000 & $86.75 \%$ \\
\hline
\end{tabular}

Bank Muamalat Indonesia's LDR Ratio in 2019, amounting to $86.75 \%$, this reinforces the following Table 15 which shows that the LDR Composite Rating (PK) Value of Bank Muamalat Indonesia, as follows:

Table 15. LDR Composite Rating (PK) Value of Bank Muamalat Indonesia

\begin{tabular}{cccc}
\hline Period & LDR \% & Rating & Remark \\
\hline 2019 & $86.75 \%$ & 3 & Enough Healthy \\
\hline
\end{tabular}


Bank Muamalat Indonesia in 2019 is expected to reduce the LDR ratio to a healthy predicate LDR ratio to maintain the level of bank liquidity risk in accordance with Bank Indonesia Regulation No. 13/1/ PBI/2011 concerning Assessment of the Soundness of Commercial Banks.

b. Good Corporate Governance (GCG)

Assessment of the GCG factor is an assessment of bank management on the implementation of GCG principles as stipulated in Bank Indonesia Regulations. The results of the achievements are based on the Annual Report of Bank Muamalat Indonesia from the self-assessment which can be seen in Table 16.

Table 16. Annual report of Bank Muamalat Indonesia from the self-assessment

\begin{tabular}{ccc}
\hline Period & Rating & Remark \\
\hline 2019 & 3 & Enough Good \\
\hline
\end{tabular}

In 2019, Bank Muamalat Indonesia was ranked 3 which shows that it is quite good in implementing it. The several awards received by Bank Muamalat Indonesia in 2019 are as follows:

1. $1^{\text {st }}$ place, Infobank's 2019 Digital Brand Award.

2. Innovative Company in Quickly Responding to Customer Problems in Islamic Digital Financial Services Category Islamic Banking, Indonesia Digital Innovations Award 2019, Warta Ekonomi.

3. Rank I SLE Index 2019 Satisfaction Loyalty Engagement Award 2019 Infobank.

4. Top 2019 Sharia General Savings an Award for Best Financial Products 2019 Warta Ekonomi.

5. The Best Digital Brand 2014-2018 Infobank Award 2019.

c. Earnings (Rentability)

The rentability ratio used in this study is Return on Assets (ROA). ROA is the result of a comparison between Profit Before Tax and Total Assets. This ratio is calculated to measure the success of management in generating profits. The smaller this ratio means that bank management is less capable of managing assets to increase revenue and reduce costs. The results of Bank Muamalat Indonesia's ROA assessment can be seen in Table 17.

Table 17. Results of Bank Muamalat Indonesia's ROA assessment

\begin{tabular}{cccc}
\hline Period & Profit before tax & Total Asset & ROA \% Ratio \\
\hline 2019 & 26.166 .000 & 50.555 .519 .000 & $0.05 \%$ \\
\hline
\end{tabular}

In 2019, the ROA ratio is very small so that it affects the next assessment category in Table 18 showing the Composite Rating (PK) Value of Bank Muamalat Indonesia's ROA.

Table 18. Composite Rating (PK) Value of Bank Muamalat Indonesia's ROA.

\begin{tabular}{cccc}
\hline Period & ROA \% & Rating & Remark \\
\hline 2019 & $0.05 \%$ & 4 & Unhealthy \\
\hline
\end{tabular}

Bank Muamalat Indonesia is expected to be able to rise to increase the ROA ratio because if the total assets of the bank used by the bank do not provide a large amount of profit, the company will experience losses and will hamper bank performance and result in bankruptcy because in the Indonesian bank regulations banks are required to maintain and / or improve Bank Soundness Level by applying prudential principles and risk management in conducting business activities.

\section{d. Capital}

Capital ratio is the ratio between Bank Capital and Risk Weighted Assets (RWA). The CAR ratio is used to measure the capital adequacy of the bank to support assets that contain or generate risk. The results of Bank Muamalat Indonesia's CAR assessment can be seen in Table 19. 
Table 19. Results of Bank Muamalat Indonesia's CAR assessment

\begin{tabular}{cccc}
\hline Period & Bank Capital & ATMR & CAR \% Ratio \\
\hline 2019 & 3.871 .341 .000 & 31.171 .834 .000 & $12,41 \%$ \\
\hline
\end{tabular}

With a CAR ratio of $12.41 \%$, then in Table 20 shows the Composite Rating (PK) Weight of Bank Muamalat Indonesia's CAR.

Table 20. Composite Rating (PK) weight of Bank Muamalat Indonesia's CAR.

\begin{tabular}{cccc}
\hline Period & CAR & Rating & Remark \\
\hline 2019 & $12,41 \%$ & 1 & Unhealthy
\end{tabular}

Bank Muamalat Indonesia is expected to be able to maintain and maintain the CAR ratio in order to face risks that might occur in the future, due to the smaller CAR ratio, the bank has the potential for difficulties and endangers the continuity of its business both in financing its business activities and the occurrence. risks in the future that can cause losses to the bank.

The soundness level of Bank Muamalat Indonesia, can be seen in the following chart:

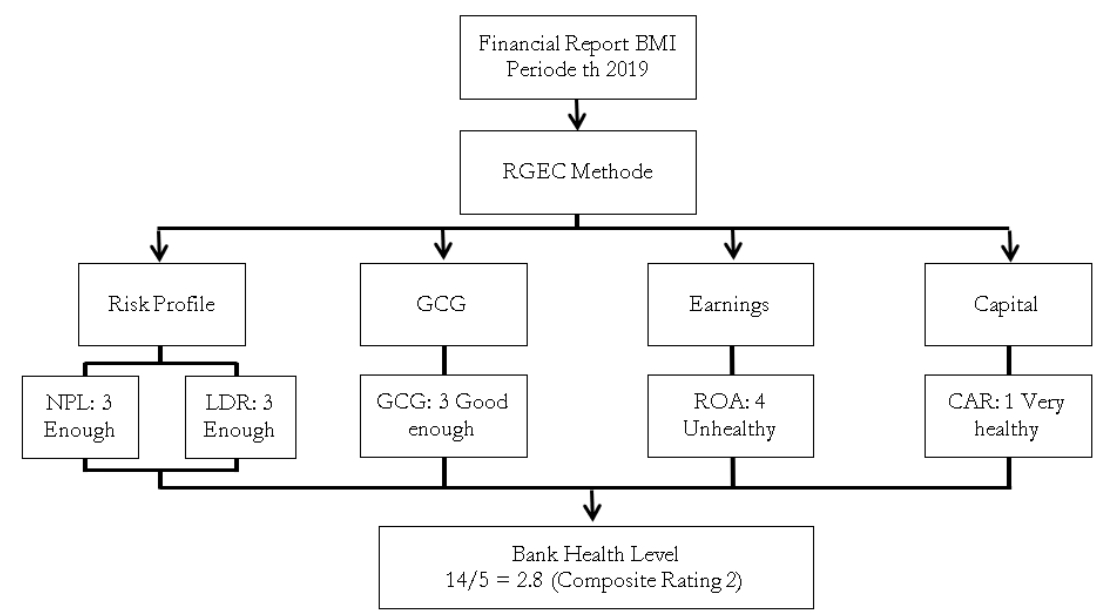

Figure 2. Soundness level of Bank Muamalat Indonesia

\section{Analysis of the Soundness of Bank Negara Indonesia Sharia}

The following is an outline of the financial data used to calculate the Bank Soundness Level ratio using the RGEC method:

Table 21. Sharia Bank Negara Indonesia

\begin{tabular}{lc}
\hline Category & 31 December 2019 \\
\hline Non Performing Credit & 1.084 .998 .382 \\
Total Credits & 32.582 .534 .000 \\
Third-party funds & 43.771 .879 .000 \\
Profit before tax & 799.949 .000 \\
Total Assets & 49.980 .235 .000 \\
Bank capital & 4.565 .800 .000 \\
ATMR & 25.030 .077 .000 \\
\hline
\end{tabular}

Source: Financial reports for the period 31 December 2019

a. Risk Profile

The financial ratios used in assessing the soundness level of a bank in terms of risk profile are credit risk using the Non-Performing Loan (NPL) ratio and liquidity risk with the Loan to Deposit Ratio (LDR), respectively discussed as follows:

1. Credit Risk with NPL ratio 
NPL is the result of a comparison between non-performing loans and total loans. The results of the Sharia Bank Negara Indonesia NPL assessment can be seen in Table 22.

Table 22. Results of the Sharia Bank Negara Indonesia NPL assessment

\begin{tabular}{cccc}
\hline Period & Non Performing Credit & Total Kredit & NPL \% Ratio \\
\hline 2019 & 1.084 .998 .382 & 32.582 .534 .000 & $3.33 \%$ \\
\hline
\end{tabular}

Furthermore, in Table 23 below shows the Composite Rating (PK) Value of Bank Negara Indonesia Sharia NPL, as follows:

Table 23. Composite Rating (PK) value of Bank Negara Indonesia Sharia NPL

\begin{tabular}{cccc}
\hline Period & NPL \% & Rating & Remark \\
\hline 2019 & $3.33 \%$ & 2 & Healthy \\
\hline
\end{tabular}

2. Liquidity Risk with LDR ratio

LDR is the result of a comparison between Total Credit and Third Party Funds (DPK). LDR of Bank Negara Indonesia Syariah can be seen in Table 24.

Table 24. LDR of Bank Negara Indonesia Syariah

\begin{tabular}{cccc}
\hline Period & Total Credit & DPK & LDR \% Ratio \\
\hline 2019 & 32.582 .534 .000 & 43.771 .879 .000 & $74.43 \%$ \\
\hline
\end{tabular}

Furthermore, Table 25 shows the LDR Composite Rating (PK) Value of Bank Negara Indonesia Syariah, as follows:

Table 25. LDR Composite Rating (PK) value of Bank Negara Indonesia Syariah

\begin{tabular}{cccc}
\hline Period & LDR \% & Rating & Remark \\
\hline 2019 & $74.43 \%$ & 2 & Healthy \\
\hline
\end{tabular}

Bank Negara Indonesia Syariah is expected to be able to increase and maintain the LDR figure to remain and increase rank 2 in the Healthy category.

b. Good Corporate Governance (GCG)

Assessment of GCG factors is an assessment of bank management on the implementation of GCG principles as stipulated in Bank Indonesia Regulations. The results of achievement are based on the Annual Report of Bank Negara Indonesia Syariah from the self-assessment which can be seen in Table 26.

Table 26. Results of achievement are based on the annual report of Bank Negara Indonesia Syariah from the self-assessment Period Rating Remark

2019 2 Good

In 2019, Bank Negara Indonesia Syariah was ranked 2 which shows that it is good in implementing it. The several awards received by Bank Negara Indonesia Syariah include:

1. BNI Syariah won 46 awards from various institutions both at home and abroad, including "Best Performance of Sharia Bank" from the Bisnis Indonesia Financial Award, "Best Sharia Bank 2019" from Investor Magazine, and "Best Islamic Finance SME Bank" from Alpha Southeast Asia 2019.

2. Predicate "Trusted Based on Corporate Governance Perception Index (CGPI)" at the 2019 Indonesia Most Trusted Companies Award.

3. 3rd Winner of the 2018 Annual Report Award for the category of Non Listed Private Financial Companies. 
4. The Best of The Best Indonesia GCG Implementation" from the Economic Review in the 2019 Indonesia Good Corporate Governance Award as evidence of good GCG implementation in 2019.

c. Earnings (Rentability)

The rentability ratio used in this study is Return on Assets (ROA). ROA is the result of the comparison between profit before tax and total assets. This ratio is calculated to measure the success of management in generating profits. The smaller this ratio means that bank management is less capable of managing assets to increase revenue and reduce costs. The results of the ROA assessment of Bank Negara Indonesia Syariah can be seen in Table 27.

Table 27. Results of the ROA assessment of Bank Negara Indonesia Syariah

\begin{tabular}{cccc}
\hline Period & Profit before tax & Total asset & ROA \% ratio \\
\hline 2019 & 799.949 .000 & 49.980 .235 .000 & $1.82 \%$ \\
\hline
\end{tabular}

Furthermore, Table 28 shows the Composite Rating (PK) Value of Bank Negara Indonesia Syariah ROA, as follows:

Table 28. Composite Rating (PK) Value of Bank Negara Indonesia Syariah ROA

\begin{tabular}{cccc}
\hline ROA \% & Rating & Remark \\
\hline 2019 & $1.82 \%$ & 1 & Very Healthy \\
\hline
\end{tabular}

Bank Negara Indonesia Syariah is expected to be able to maintain the ROA ratio because if the total assets of the bank are used if the bank does not provide profit or at least the profit earned, the company will suffer losses and will hinder the bank's performance.

\section{d. Capital}

The capital ratio used in this study is the Capital Adequacy Ratio (CAR). CAR is a comparison between Bank Capital and Risk Weighted Assets (RWA). The CAR ratio is used to measure the capital adequacy of the bank to support assets that contain or generate risk. The results of Bank Negara Indonesia Syariah CAR assessment can be seen in Table 29.

Table 29. Results of Bank Negara Indonesia Syariah CAR assessment

\begin{tabular}{cccc}
\hline Period & Bank Capital & ATMR & CAR \% Ratio \\
\hline 2019 & 4.565 .800 .000 & 25.030 .077 .000 & $18.24 \%$ \\
\hline
\end{tabular}

Furthermore, the table shows the Composite Rating (PK) Weight of Bank Negara Indonesia Syariah CAR, as follows:

Table 30. Composite Rating (PK) weight of Bank Negara Indonesia Syariah CAR

\begin{tabular}{cccc}
\hline Period & CAR & Rating & Remark \\
\hline 2019 & $18.24 \%$ & 1 & Very Healthy \\
\hline
\end{tabular}


The soundness level of Bank Negara Indonesia Syariah, can be seen in the following chart:

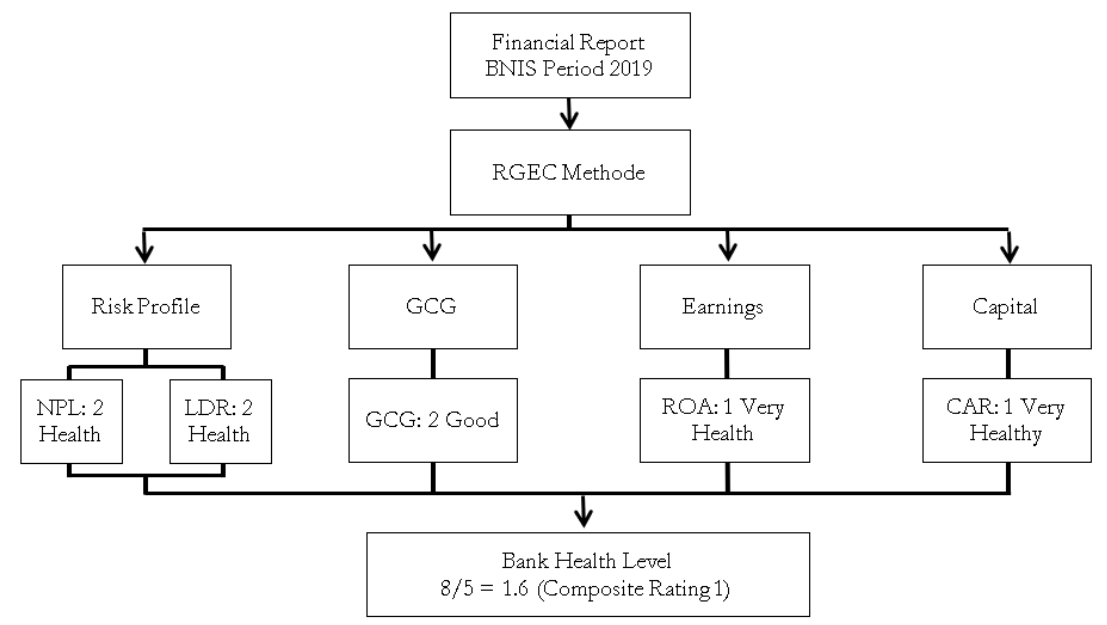

Figure 3. The soundness level of Bank Negara Indonesia Syariah

\section{Conclusion}

Bank Negara Indonesia Syariah is expected to be able to maintain and maintain the CAR ratio in order to face risks that might occur in the future, due to the smaller CAR ratio, the bank has the potential for difficulties and endangers its business continuity both in financing its business activities and the occurrence of risks in the future that can cause losses to the bank.

\section{References}

Laporan Publikasi Kuartal 31 Desember 2019 Bank Syariah Mandiri.

Laporan Publikasi Kuartal 31 Desember 2019 Bank Muamalat Indonesia.

Laporan Publikasi Kuartal 31 Desember 2019 Bank Negeri Indonesia Syariah.

Laporan Tahun 2019 Bank Syariah Mandiri.

Laporan Tahun 2019 Bank Muamalat Indonesia.

Laporan Tahun 2019 Bank Negeri Indonesia Syariah.

Peraturan Bank Indonesia No. 13/1/PBI/2011 tanggal 5 Oktober 2011, tentang Penilaian Kesehatan Bank.

Peraturan Otoritas Jasa Keuangan Tentang Penilaian Tingkat Kesehatan Bank Umum No. 4/POJK.03/2016.

Sari, K.R. (2017). Analisis Tingkat Kesehatan Bank dengan Menggunakan Metode RGEC Pada Bank Umum BUMN Yang Terdaftar di Bursa Efek Indonesia Periode 2013-2015. Yogyakarta: Fakultas Ekonomi Universitas Negeri Yogyakarta.

Surat Edaran Bank Indonesia No. 13/6/DPNP tanggal 18 Februari 2011, tentang Pedoman Perhitungan Aset Tertimbang Menurut Risiko Untuk Risiko Kredit dengan Menggunakan Pendekatan Standar.

Surat Edaran Bank Indonesia No. 13/24/DPNP/2011 dan No. 6/23/DPNP/2004 Tentang Kodifikasi Penilaian Tingkat Kesehatan Bank Umum. 